\title{
Hexaconazole and sodium selenate effectiveness on the productivity of Moringa oleifera
}

\author{
Aisha M. A. Ahmed ${ }^{1 *}$, Iman M. Talaat ${ }^{1}$ and Khalid A. Khalid ${ }^{2}$
}

\begin{abstract}
Background and objective: Moringa oleifera is a small tree used in human nutrition and medical proposes because it contains some components such as protein, vitamins, fatty acids, nutrients, and phenolic components; the new literature indicated that M. oleifera has antioxidant and anticancer activities. Hexaconazole (HEXAC) and sodium selenate (SODSE) play important roles in physiological processes in M. oleifera. Various techniques of research work are using to modify the quantity and quality of medicinal crops that are natural source for food and pharmaceutical industries. Adding HEXAC and SODSE are two ways of research that have the potential to increase the productivity of medicinal plants. Thus, the aim of this trial was to evaluate the growth measurements, yield, and chemical content of $M$. oleifera due to the HEXAC and SODSE treatments.
\end{abstract}

Materials and methods: Plants were exposed to HEXAC (5 and $10 \mathrm{mg} / \mathrm{L}$ ), SODSE (30 and $60 \mathrm{mg} / \mathrm{L}$ ), and control treatments. Morphological characters [leaf number/plant, stem length $(\mathrm{cm})$, fresh weight of shoot $(\mathrm{g} / \mathrm{plant})$, dry weights of shoot (g/plant), root length $(\mathrm{cm})$, fresh weight of root $(\mathrm{g} / \mathrm{plant})$, and dry weight of root $(\mathrm{g} / \mathrm{plant})]$ were recorded during the vegetative and flowering stages while pod and seed weights ( $\mathrm{g} / \mathrm{plant}$ ) were recorded at the fruiting stage. Photosynthetic pigments, protein, and the activities of antioxidant enzymes were recorded at both of vegetative and flowering stages. Data were statistically analyzed using two-way analysis of variance.

Results: The $5 \mathrm{mg} / \mathrm{L}$ of SODSE resulted in the highest values of growth, yield, photosynthetic pigments, protein, and antioxidant enzymes (identified in leaves) while $30 \mathrm{mg} / \mathrm{L}$ of HEXAC produced the greatest amounts of protein that identified in roots.

Conclusion: The SODSE and HEXAC caused significant increases on growth, yield, and chemical constituents of $M$. oleifera. This research paper discovered that $M$. oleifera plants can be successfully grown under SODSE and HEXAC as they possess relatively high yield and chemical constituents. So this trial will help the farmers, ministry of agriculture, and drug companies to improve the yield and active components (protein) as natural sours of drug industries.

Keywords: Moringa oleifera, Hexaconazole, Sodium selenate, Growth, Yield, Protein and chemical contents

\footnotetext{
* Correspondence: aishazyat@yahoo.com

'Botany Department, National Research Centre, Dokki, Cairo, Egypt

Full list of author information is available at the end of the article
} 


\section{Background}

Moringa oleifera is a small tree that belongs to family Moringaceae used for certain nutrition and medical proposes (Farooq et al. 2012). It contains various constituents such as protein, vitamins, oils, fatty acids, elements, and phenolic compounds. Previous investigators indicated that $M$. oleifera has an anti-inflammatory, antimicrobial, antioxidant, anticancer, cardiovascular, hepatoprotective, anti-ulcer, diuretic, antiurolithiatic, and antihelmintic characters (Farooq et al. 2012).

The growth, yield, and chemical constituents of medicinal crops can be increased by various ways such as nutrition, irrigation, and plant growth regulators (Fletcher et al. 2000; Yassen and Khalid 2009; Khalid and Shedeed 2014; Khalid and Ahmed 2017). Manipulation of medicinal plants production with chemicals is one of the most important aims for agricultural achievements. Hexaconazole (HEXAC) and sodium selenate (SODSE) could be used to modify growth, yield, and chemical constituents of medicinal plants (Fletcher et al. 2000; Germ and Stibilj 2007; Ahmed et al. 2018).

The HEXAC is one of triazole components which has the properties of fungicidal and plant growth regulators. It can induce some changes in plant morphological characters, protein, gibberellin synthesis, carbohydrate values, and synthesis of cytokinin and abscisic acid (ABA) contents (Fletcher et al. 2000; Jaleel et al. 2016). The HEXAC application resulted in various increases in chlorophyll and soluble protein of okra and chili (Mareeswari 2002). Application of HEXAC caused significant increases in the yield and antioxidant enzymes activities of carrot and cassava plants (Gomathinayagam et al. 2007; Gopi et al. 2007). Cucumber plants treated with HEXAC produced different variations in growth characters, photosynthetic pigments, and the activities of antioxidant enzymes such as catalase (CAT), ascorbate peroxidase (APX), superoxide dismutase (SOD), and peroxidase (POD) (Kim and Hong 2012). The common bean plants treated with $2 \mathrm{mg} / \mathrm{L}$ (as a foliar application) resulted in significant increments in growth, yield components, total chlorophyll, and antioxidant enzymes activities (Chehelpar et al. 2016). Slight changes were observed in the rate of seed germination and biomass production of Cicer arietinumand and Zea mays plants under HEXAC treatments. The growth characters of sweet potato were significantly improved with HEXAC treatments especially at $3 \mathrm{mg} / \mathrm{L}$ (Sivakumar et al. 2009; Dhanamanjuri et al. 2013; Haya et al. 2017).

Previous investigations recommended the inorganic form of selenium (Se) such as selenate to use in plant nutrition because it is the most available one for plants (Ebrahimi et al. 2014). Low doses of SODSE are recommended with different crops; it has a known role in the balance of plant hormone, antioxidant activities, and several physiological processes in a plant cell. It can promote glutathione peroxidase (GSH-Px) activities which increase the resistance to substandard biotic factors affecting crops (Csiszr et al. 2004; Djanaguiraman et al. 2005; Filek et al. 2008; Cartes et al. 2010). Different enhancements were occurred in growth characters, yield, and photosynthetic pigments of some crops such as alfalfa, chives, tomato, peanut, and celery under the treatments of SODSE (Hawrylak-Nowak 2009; Chamheidar and Parvanak 2014; Nancy and Arulselvi 2014; Jozwiak et al. 2016; Irmak 2017; Khalid et al. 2017; Ahmed et al. 2018). Application of SODSE resulted in highly significant increases of Brassica rapa L. seed yield (Lyons et al. 2009). The Spirulina platensis plants were exposed to different levels of SODSE and the enzyme activities [(glutathione peroxidase (GPX), superoxide dismutase (SOD), catalase (CAT), and Guadep peroxidases (POD)] were investigated; obtained results indicated that the SODSE levels (less than $175 \mathrm{mg} / \mathrm{L}$ ) caused significant increases in the activities of all enzymes (GPX, SOD, CAT, and POD) (Chen et al. 2008). The treatments of SODSE enhanced antioxidant enzymes (especially CAT) in tomato plants (Nancy and Arulselvi 2014; Mozafariyan et al. 2017). The SODSE application resulted in high retention in the lettuce plants, with a maximum of 97.5\% retained in the edible portion (Kathleen et al. 2003). The SODSE dose at $1 \mathrm{mg} / \mathrm{L}$ increased the total protein by $25 \%$ compared with the control of tomato fruits (Nancy and Arulselvi 2014). Protein contents of peanut were not affected under SODSE treatments (Irmak 2017).

Adding HEXAC and SODSE are two ways to increase the production of medicinal plants. So the influences of HEXAC and SODSE on the growth, yield, photosynthetic pigments, protein, and the activities of antioxidant enzymes of $M$. oleifera were estimated.

\section{Materials and methods}

\section{Plant materials and experimental conditions}

Two pot experiments were conducted in a greenhouse of the National Research Centre, Dokki, Cairo, Egypt, during two seasons of $2016 / 2017$ and $2017 / 2018$. The M. oleifera seeds were obtained from the Department of Medicinal and Aromatic Plants (MAP), Ministry of Agriculture, Giza, Egypt. Ten seeds were sown in each clay pot (30 cm diameter) in the second week of March during both seasons. Each pot was filled with 
$10 \mathrm{~kg}$ of air-dried clay:sand $(1: 1, V: V)$ mix. Six weeks after sowing, seedlings were thinned to three plants per pot. Pots were divided into three groups. The first group was exposed to HEXAC at 30 or $60 \mathrm{mg} / \mathrm{L}$. The second group was subjected to SODSE (as Se) at 5 or $10 \mathrm{mg} / \mathrm{L}$. The third group was subjected to distilled water (as control). The HEXAC and SODSE were applied to run-off to foliage at 6 and 7 weeks after sowing. All agricultural practices were conducted according to the recommendations by the Egyptian Ministry of Agriculture.

\section{Morphological characters}

Morphological characters $(\mathrm{MCH})$, such as leaf number (LEN), stem length (STL), fresh weight of shoot (FWSH), dry weight of shoot (DWSH), root length (ROL), fresh weight of root (FWR), and dry weight of root (DWR), were recorded during the various growth stages (GRS), i.e., vegetative stage (VST) [120 days after sowing (120 DAS)], flowering stage (FST) [210 days after sowing (210 DAS)]. During the fruiting stage [255 days after sowing (255 DAS)], the pod weight (PW) and seed weight (SW) were recorded.

\section{Determination of photosynthetic pigments}

Chlorophyll (CHL a, CHL b) and total carotenoids (TOC) in fresh leaves which were collected at VST and FST of each treatment were determined using methods described by Anonymous (2016).

\section{Extraction and estimation of nitrogenous constituents}

The soluble protein, insoluble protein, and total protein were estimated in leaves and roots, and then calculated according to the method described by Daughaday et al. (1952).

Extraction and assaying antioxidant enzymes activities Enzyme extraction was with the method described by Mukherjee and Choudhuri (1983). Catalase activity (CAT) EC 1.11.1.6 was assayed according to the method of Kar and Mishra (1976). Peroxidase activity (POX) EC 1.11.1.7 was assayed with the method of Kar and Mishra (1976) with slight modifications.

\section{Statistical analysis}

The experiment was arranged as a $2 \times 2 \times 2$ factorial (HEXAC, SODSE, growth stages) with four replicates using a randomized complete block design using

Table 1 Effect of HEXAC or SODSE on the MCH

\begin{tabular}{|c|c|c|c|c|c|c|c|c|c|}
\hline \multirow{2}{*}{$\begin{array}{l}\text { GRS } \\
\text { VST }\end{array}$} & \multicolumn{2}{|c|}{$\begin{array}{l}\text { Treatments } \\
(\mathrm{mg} / \mathrm{L})\end{array}$} & \multirow{2}{*}{$\begin{array}{l}\text { LEN/ } \\
\text { plant } \\
7.0 \pm 0.0\end{array}$} & \multirow{2}{*}{$\begin{array}{l}\mathrm{STL}(\mathrm{cm}) \\
138.7 \pm 0.9\end{array}$} & \multirow{2}{*}{$\begin{array}{l}\text { FWSH } \\
\text { g/plant } \\
80.9 \pm 0.1\end{array}$} & \multirow{2}{*}{$\begin{array}{l}\text { DWSH } \\
43.8 \pm 0.0\end{array}$} & \multirow{2}{*}{$\begin{array}{l}\mathrm{ROL}(\mathrm{cm}) \\
13.7 \pm 0.0\end{array}$} & \multirow{2}{*}{$\begin{array}{l}\text { FWR } \\
\text { g/plant } \\
28.6 \pm 0.0\end{array}$} & \multirow{2}{*}{$\begin{array}{l}\text { DWR } \\
21.5 \pm 0.0\end{array}$} \\
\hline & Control & 0 & & & & & & & \\
\hline & HEXAC & 30 & $9.3 \pm 0.6$ & $151.0 \pm 0.5$ & $114.0 \pm 0.1$ & $61.8 \pm 0.1$ & $20.8 \pm 0.2$ & $39.8 \pm 0.0$ & $30.0 \pm 0.0$ \\
\hline & & 60 & $7.3 \pm 0.6$ & $142.7 \pm 0.9$ & $113.1 \pm 0.1$ & $61.0 \pm 0.1$ & $19.3 \pm 0.2$ & $36.8 \pm 0.1$ & $27.7 \pm 0.1$ \\
\hline & SODSE & 5 & $10.7 \pm 0.6$ & $167.3 \pm 0.8$ & $142.0 \pm 0.2$ & $77.0 \pm 0.1$ & $23.4 \pm 0.1$ & $58.9 \pm 0.1$ & $44.4 \pm 0.1$ \\
\hline & & 10 & $10.0 \pm 1.0$ & $163.0 \pm 0.4$ & $137.2 \pm 0.1$ & $74.4 \pm 0.1$ & $22.9 \pm 0.1$ & $52.9 \pm 0.1$ & $39.8 \pm 0.1$ \\
\hline Overall VST & & & $8.7 \pm 1.6$ & $152.5 \pm 2.5$ & $117.4 \pm 2.2$ & $63.6 \pm 2.1$ & $20.0 \pm 1.3$ & $43.4 \pm 1.3$ & $32.7 \pm 1.8$ \\
\hline \multirow[t]{5}{*}{ FST } & Control & 0 & $13.3 \pm 0.5$ & $243.7 \pm 0.3$ & $305.1 \pm 0.0$ & $165.4 \pm 0.0$ & $20.5 \pm 0.1$ & $56.2 \pm 0.0$ & $42.3 \pm 0.0$ \\
\hline & HEXAC & 30 & $15.0 \pm 1.0$ & $247.7 \pm 0.6$ & $317.6 \pm 0.1$ & $172.1 \pm 0.0$ & $25.7 \pm 0.1$ & $64.2 \pm 0.1$ & $48.4 \pm 0.1$ \\
\hline & & 60 & $13.3 \pm 0.6$ & $245.3 \pm 0.3$ & $312.5 \pm 0.0$ & $169.4 \pm 0.0$ & $22.4 \pm 0.1$ & $63.2 \pm 0.2$ & $47.6 \pm 0.1$ \\
\hline & SODSE & 5 & $17.0 \pm 1.0$ & $251.7 \pm 0.6$ & $391.4 \pm 0.0$ & $212.2 \pm 0.0$ & 28.00 .1 & $86.3 \pm 0.0$ & 65.00 .0 \\
\hline & & 10 & $15.0 \pm 1.0$ & $249.7 \pm 0.6$ & $341.8 \pm 0.1$ & $185.3 \pm 0.1$ & $26.2 \pm 0.1$ & $73.8 \pm 0.2$ & $57.8 \pm 0.1$ \\
\hline Overall FST & & & $14.7 \pm 1.6$ & $247.6 \pm 2.7$ & $333.7 \pm 3.3$ & $180.9 \pm 1.7$ & $24.6 \pm 1.8$ & $69.3 \pm 1.2$ & $52.2 \pm 1.4$ \\
\hline \multirow[t]{5}{*}{ Overall treatments } & Control & 0 & $10.2 \pm 1.5$ & $191.2 \pm 5.7$ & $193.0 \pm 2.2$ & $104.6 \pm 1.6$ & $17.1 \pm 1.3$ & $42.4 \pm 1.5$ & $31.9 \pm 1.4$ \\
\hline & HEXAC & 30 & $12.2 \pm 1.3$ & $199.3 \pm 5.3$ & $215.8 \pm 1.2$ & $117.0 \pm 1.6$ & $23.2 \pm 1.6$ & $52.0 \pm 1.4$ & $39.2 \pm 1.9$ \\
\hline & & 60 & $10.3 \pm 1.3$ & $194.0 \pm 5.6$ & $212.8 \pm 1.9$ & $115.2 \pm 1.9$ & $20.8 \pm 1.7$ & 50.01 .4 & $37.6 \pm 1.9$ \\
\hline & SODSE & 5 & $13.8 \pm 1.5$ & $209.5 \pm 4.6$ & $266.7 \pm 1.6$ & $144.6 \pm 1.7$ & $25.7 \pm 1.5$ & $72.6 \pm 1.5$ & $54.7 \pm 1.3$ \\
\hline & & 10 & $12.5 \pm 1.9$ & $206.3 \pm 4.7$ & $239.5 \pm 1.2$ & $129.8 \pm 1.7$ & $24.6 \pm 1.8$ & $64.8 \pm 1.3$ & $48.8 \pm 1.9$ \\
\hline \multicolumn{10}{|l|}{$F$ ratio } \\
\hline Treatments & & & $25.4^{* * *}$ & $972.3 * * *$ & $715,031.4^{* * *}$ & $492,053.0^{* * *}$ & $5514.5^{* * *}$ & $116,479.8^{* * *}$ & $4211.3^{* * *}$ \\
\hline GRS & & & $455.5^{* * *}$ & $179,477.1^{* * *}$ & $5,212,461.0^{* * *}$ & $358,278.0^{* * *}$ & $11,991.1^{* * *}$ & $662,459.3^{* * *}$ & $48962.5^{* * *}$ \\
\hline Treatments $\times$ GRS & & & $0.8 \mathrm{~ns}$ & $342.3^{* * *}$ & $96,818.3^{* * *}$ & $65,894.7^{* * *}$ & $260.5^{* * *}$ & $582.6^{* * *}$ & $4617.9^{* * *}$ \\
\hline
\end{tabular}


STAT-ITCF program (Statistica, ver. 7. 1, Statsoft Inc., Tulsa, OK) (2007). According to De-Smith (2015), averages of data of both seasons were analyzed using two-way analysis of variance. Significant values were determined according to $P$ values $(P<0.05=$ significant $\left(^{*}\right), P<0.01=$ moderate significant $(* *)$, and $P<$ $0.001=$ highly significant $\left.\left({ }^{* * * *}\right)\right)$. Data were given as mean \pm standard divination (SD).

\section{Results}

\section{Effect of HEXAC or SODSE on the MCH during various GRS}

The MCH such as LEN/plant, STL $(\mathrm{cm})$, FWSH (g/ plant), DWSH (g/plant), ROL (cm), FWR (g/plant), and DWR (g/plant) were increased with various doses of HEXAC or SODSE during VST and FST compared with control (Table 1). The M. oleifera plants produced higher values of $\mathrm{MCH}$ at FST than VST. The highest $\mathrm{MCH}$ were produced with the dose of $5 \mathrm{mg} / \mathrm{L}$ (SODSE) at FST with the values of 17.0, 251.7, 391.4, 212.2, 28.0, 86.3 , and 65.0, respectively (Table 1 ). Increases in all $\mathrm{MCH}$ were highly significant for HEXAC or SODSE levels, GRS and various levels of HEXAC, or SODSE $\times$ GRS except the LEN was insignificant for interaction. Highly significant increases were obtained in the PW and SW under HEXAC or SODSE doses. The highest PW and SW were produced due to the SODSE at $5 \mathrm{mg} / \mathrm{L}$ with the values of 142.7 and $71.3 \mathrm{~g} /$ plant respectively (Table 2).

\section{Effect of HEXAC or SODSE on PHOSP content $(\mathrm{mg} / \mathrm{g})$ during various GRS}

The doses of HEXAC or SODSE resulted in increments in PHOSP (CHL a, CHL b, and TOC) at VST and FST (Table 3). The FST recorded higher values in PHOSP than VST. The highest amounts of CHL a, $\mathrm{CHL} b$, and TOC were recorded with the treatment of $5 \mathrm{mg} / \mathrm{L}$ SODSE during the FST with values of $10.3,8.0$, and $3.1 \mathrm{mg} / \mathrm{g}$ respectively (Table 3 ). The increases in all PHOSP were highly significant for HEXAC or SODSE, various stages and their

Table 2 Effect of HEXAC or SODSE on PW and SW

\begin{tabular}{llll}
\hline Treatments $(\mathrm{mg} / \mathrm{L})$ & \multicolumn{3}{c}{$\begin{array}{l}\text { SW } \\
\text { g/plant }\end{array}$} \\
\hline Control & 0 & $98.7 \pm 1.0$ & $37.4 \pm 3.2$ \\
HEXAC & 30 & $121.6 \pm 4.5$ & $46.8 \pm 0.8$ \\
& 60 & $116.6 \pm 3.4$ & $42.8 \pm 2.0$ \\
SODSE & 5 & $142.7 \pm 0.7$ & $71.3 \pm 0.3$ \\
& 10 & $131.6 \pm 2.0$ & $59.3 \pm 1.0$ \\
F ratio & & $32.6^{* * *}$ & $174.7^{* * *}$ \\
\hline
\end{tabular}

*** highly significant
Table 3 Effect of HEXAC or SODSE On PHOSP

\begin{tabular}{|c|c|c|c|c|c|}
\hline \multirow[t]{2}{*}{ GRS } & \multirow{2}{*}{\multicolumn{2}{|c|}{$\begin{array}{l}\text { Treatments } \\
(\mathrm{mg} / \mathrm{L})\end{array}$}} & \multicolumn{3}{|l|}{ PHOTSP } \\
\hline & & & $\mathrm{CHL}$ a & $\mathrm{CHL} b$ & TOC \\
\hline \multirow{6}{*}{ VST } & & & & & \\
\hline & Control & 0 & $4.4 \pm 0.1$ & $2.3 \pm 0.0$ & $0.7 \pm 0.0$ \\
\hline & HEXAC & 30 & $6.6 \pm 0.3$ & $4.1 \pm 0.1$ & $2.0 \pm 0.1$ \\
\hline & & 60 & $5.4 \pm 0.1$ & $3.5 \pm 0.0$ & $2.0 \pm 0.2$ \\
\hline & SODSE & 5 & $8.3 \pm 0.1$ & $4.5 \pm 0.0$ & $1.9 \pm 0.3$ \\
\hline & & 10 & $8.0 \pm 0.1$ & $4.1 \pm 0.6$ & $1.9 \pm 0.1$ \\
\hline Overall VST & & & $6.5 \pm 1.6$ & $3.7 \pm 0.8$ & $1.7 \pm 0.6$ \\
\hline \multirow[t]{5}{*}{ FST } & Control & 0 & $8.5 \pm 0.0$ & $3.6 \pm 1.4$ & $1.8 \pm 0.1$ \\
\hline & HEXAC & 30 & $9.6 \pm 0.1$ & $4.7 \pm 1.0$ & $2.1 \pm 0.1$ \\
\hline & & 60 & $9.4 \pm 0.1$ & $4.5 \pm 0.5$ & $2.0 \pm 0.2$ \\
\hline & SODSE & 5 & $10.3 \pm 0.0$ & $8.0 \pm 0.7$ & $3.1 \pm 0.1$ \\
\hline & & 10 & $9.3 \pm 0.0$ & $4.7 \pm 0.9$ & $2.2 \pm 0.2$ \\
\hline Overall FST & & & $9.4 \pm 0.6$ & $5.1 \pm 0.8$ & $2.2 \pm 0.5$ \\
\hline \multirow[t]{5}{*}{ Overall treatments } & Control & 0 & $6.5 \pm 2.2$ & $3.0 \pm 1.2$ & $1.3 \pm 0.6$ \\
\hline & HEXAC & 30 & $8.1 \pm 1.7$ & $4.4 \pm 0.7$ & $2.0 \pm 0.1$ \\
\hline & & 60 & $7.4 \pm 2.2$ & $4.0 \pm 0.7$ & $2.1 \pm 0.2$ \\
\hline & SODSE & 5 & $9.3 \pm 1.1$ & $6.3 \pm 1.1$ & $2.6 \pm 0.5$ \\
\hline & & 10 & $8.6 \pm 0.7$ & $4.4 \pm 0.7$ & $2.1 \pm 0.2$ \\
\hline \multicolumn{6}{|l|}{ F ratio } \\
\hline Treatments & & & $630.4^{* * *}$ & $16.4^{* * *}$ & $51.1^{* * *}$ \\
\hline GRS & & & $5419.0^{* * *}$ & $28.3^{* * *}$ & $68.3^{* * *}$ \\
\hline Treatments $\times$ GRS & & & $198.3^{* * *}$ & $4.1^{*}$ & $15.7^{* * *}$ \\
\hline
\end{tabular}

interactions except the $\mathrm{CHL} b$ was significant for HEXAC or SODSE $\times$ growth stages.

\section{Effect of HEXAC or SODSE on the proteins content at different GRS}

Application of HEXAC or SODSE as foliar spray, GST, and the interaction affect soluble, insoluble, and total protein that identified in leaves and roots (Table 4). The HEXAC or SODSE doses resulted in different increments in the protein contents of leaves or roots at various GRS compared with control. Lower values in protein levels were found during VST than FST. The dose of $5 \mathrm{mg} / \mathrm{L}$ (SODSE) produced the greatest amounts of soluble, insoluble, and total protein in leaves with the values of 10.7, 5.3, and $16.0 \mathrm{mg} / \mathrm{g}$, respectively. On the other hand, the highest amounts of soluble, insoluble, and total protein in roots $(4.7,2.8$, and $7.6 \mathrm{mg} / \mathrm{g}$ ) were occurred with HEXAC at $30 \mathrm{mg} / \mathrm{L}$. The changes in all proteins values were highly significant for HEXAC or SODSE, GRS, and the interactions except the insoluble protein of leaves was significant for the interactions. 
Table 4 Effect of HEXAC or SODSE on the proteins content

\begin{tabular}{|c|c|c|c|c|c|c|c|c|}
\hline \multirow[t]{4}{*}{ GRS } & \multicolumn{2}{|c|}{ Treatments (mg/L) } & \multicolumn{6}{|c|}{ Protein contents } \\
\hline & & & \multicolumn{3}{|l|}{ Leaves } & \multicolumn{3}{|l|}{ Roots } \\
\hline & & & Soluble & Insoluble & Total & Soluble & Insoluble & Total \\
\hline & & & $\mathrm{mg} / \mathrm{g}$ & & & & & \\
\hline \multirow[t]{5}{*}{ VST } & Control & 0 & $7.7 \pm 0.3$ & $3.2 \pm 0.3$ & $10.9 \pm 0.3$ & $2.1 \pm 0.1$ & $1.2 \pm 0.1$ & $3.3 \pm 0.1$ \\
\hline & HEXAC & 30 & $8.6 \pm 0.3$ & $3.8 \pm 0.1$ & $12.4 \pm 0.3$ & $3.9 \pm 0.0$ & $1.7 \pm 0.0$ & $5.6 \pm 0.0$ \\
\hline & & 60 & $8.1 \pm 0.1$ & $3.4 \pm 0.1$ & $11.6 \pm 0.1$ & $3.1 \pm 0.0$ & $1.6 \pm 0.0$ & $4.7 \pm 0.0$ \\
\hline & SODSE & 5 & $9.5 \pm 0.4$ & $4.3 \pm 0.1$ & $13.8 \pm 0.4$ & $3.0 \pm 0.1$ & $1.4 \pm 0.1$ & $4.4 \pm 0.1$ \\
\hline & & 10 & $9.2 \pm 0.3$ & $4.1 \pm 0.0$ & $13.3 \pm 0.3$ & $2.5 \pm 0.0$ & $1.3 \pm 0.1$ & $3.8 \pm 0.0$ \\
\hline Overall VST & & & $8.6 \pm 0.7$ & $3.8 \pm 0.4$ & $12.4 \pm 1.1$ & $2.9 \pm 0.6$ & $1.4 \pm 0.2$ & $4.4 \pm 0.8$ \\
\hline \multirow[t]{5}{*}{ FST } & Control & 0 & $8.8 \pm 0.1$ & $3.9 \pm 0.2$ & $12.7 \pm 0.3$ & $2.7 \pm 0.2$ & $1.7 \pm 0.0$ & $4.4 \pm 0.1$ \\
\hline & HEXAC & 30 & $9.7 \pm 0.1$ & $4.8 \pm 0.0$ & $14.6 \pm 0.1$ & $4.7 \pm 0.2$ & $2.8 \pm 0.1$ & $7.6 \pm 0.1$ \\
\hline & & 60 & $9.0 \pm 0.1$ & $4.6 \pm 0.1$ & $13.6 \pm 0.0$ & $4.5 \pm 0.1$ & $2.0 \pm 0.1$ & $6.5 \pm 0.1$ \\
\hline & SODSE & 5 & $10.7 \pm 0.3$ & $5.3 \pm 0.1$ & $16.0 \pm 0.4$ & $3.5 \pm 0.2$ & $1.9 \pm 0.0$ & $5.3 \pm 0.1$ \\
\hline & & 10 & $9.1 \pm 0.1$ & $4.8 \pm 0.1$ & $13.9 \pm 0.1$ & $3.0 \pm 0.1$ & $1.7 \pm 0.0$ & $4.8 \pm 0.1$ \\
\hline Overall FST & & & $9.5 \pm 0.7$ & $4.7 \pm 0.5$ & $14.1 \pm 1.2$ & $3.7 \pm 0.8$ & $2.0 \pm 0.4$ & $5.7 \pm 1.2$ \\
\hline \multirow[t]{5}{*}{ Overall treatments } & Control & 0 & $8.3 \pm 0.6$ & $3.5 \pm 0.4$ & $11.8 \pm 1.0$ & $2.4 \pm 0.4$ & $1.4 \pm 03$ & $3.9 \pm 0.6$ \\
\hline & HEXAC & 30 & $9.1 \pm 0.7$ & $4.3 \pm 0.6$ & $13.5 \pm 1.2$ & $4.3 \pm 0.5$ & $2.3 \pm 0.7$ & $6.6 \pm 1.1$ \\
\hline & & 60 & $8.5 \pm 0.5$ & $4.0 \pm 0.6$ & $12.6 \pm 1.1$ & $3.8 \pm 0.8$ & $1.8 \pm 0.3$ & $5.6 \pm 1.0$ \\
\hline & SODSE & 5 & $10.1 \pm 0.7$ & $4.8 \pm 0.6$ & $14.9 \pm 1.2$ & $3.2 \pm 0.3$ & $1.6 \pm 0.3$ & $4.9 \pm 0.5$ \\
\hline & & 10 & $9.2 \pm 0.2$ & $4.4 \pm 0.4$ & $13.6 \pm 0.4$ & $2.7 \pm 0.3$ & $1.5 \pm 0.2$ & $4.3 \pm 0.5$ \\
\hline \multicolumn{9}{|l|}{ F ratio } \\
\hline Treatments & & & $259.6^{* * *}$ & $71.6^{* * *}$ & $21.5^{* * *}$ & $259.6^{* * *}$ & $154.5^{* * *}$ & $682.7^{* * *}$ \\
\hline GRS & & & $317.9^{* * *}$ & $320.6^{* * *}$ & $343.1^{* * *}$ & $317.9 * * *$ & $699.6^{* * *}$ & $1374.0^{* * *}$ \\
\hline Treatments $\times$ GRS & & & $16.7^{* * *}$ & $3.5^{*}$ & $10.3^{* * *}$ & $16.7^{* * *}$ & $41.6^{* * *}$ & $42.9^{* * *}$ \\
\hline
\end{tabular}

* significant

*** highly significant

Effect of HEXAC or SODSE on the activities of antioxidant enzymes during GRS

As shown in Table 5, different increases were occurred in the antioxidant enzymes activities [CAT and POX (unit/gFW/min)] in leaves and roots under the levels of HEXAC or SODSE at VST and FST. The greatest activities of CAT and POX were produced under SODSE at $5 \mathrm{mg} / \mathrm{L}$ that recorded the values of 24.8 , $2.7 \mathrm{unit} / \mathrm{gFW} / \mathrm{min}$; 10.7, $1.7 \mathrm{unit} / \mathrm{gFW} / \mathrm{min}$ of leaves and roots, respectively. The increments in both enzyme activities were highly significant for various treatments, growth stages, and their interactions except the CAT activity was insignificant for different treatments $\times$ both VST and FST.

\section{Discussion}

The obtained results showed that different levels of HEXAC or SODSE caused various increases in $\mathrm{MCH}, \mathrm{PW}, \mathrm{SW}, \mathrm{PHOSP}$, protein, and the activities of antioxidant enzymes at VST and FST. The increase in $\mathrm{MCH}, \mathrm{PW}$, and SW with HEXAC treatments may be due to HEXAC which produce an increase in cytokinin levels of $M$. oleifera plants (Gopi et al. 2007) that reflect increases in the cell division and ultimately paved the way to the increase of $\mathrm{MCH}, \mathrm{PW}$, and SW. On the other hand, the increase in PHOSP with HEXAC doses is attributed to the ability of triazoles (such as HEXAC) to improve the cytokinin values and thereby the stimulation of PHOSP and protein biosynthesis (Gopi et al. 2007). It can be noted that higher PHOSP and protein in the leaves resulted in an increase of FW and DW of Daucus carota L (Gopi et al. 2007; Feng et al. 2003). The HEXAC have been shown to improve the activities of antioxidant enzymes such as CAT and POX, especially under abiotic stress factors against free radical damage (Hojati et al. 2011). The current results are in accordance with those obtained by Zhang et al. (2007) and Chehelpar et al. (2016); they indicated that HEXAC resulted in higher activities of antioxidant enzymes of soybean and common bean than untreated plant. 
Table 5 Effect of HEXAC or SODSE on the activities of antioxidant enzymes

\begin{tabular}{|c|c|c|c|c|c|c|}
\hline \multirow[t]{4}{*}{ GRS } & \multicolumn{2}{|c|}{ Treatments (mg/L) } & \multicolumn{4}{|c|}{ Activities of antioxidant enzymes } \\
\hline & & & \multicolumn{2}{|l|}{ CAT } & \multicolumn{2}{|l|}{ POX } \\
\hline & & & Leaves & Roots & Leaves & Roots \\
\hline & & & \multicolumn{4}{|c|}{ Unit/gFW/min } \\
\hline \multirow[t]{5}{*}{ VST } & Control & 0 & $15.2 \pm 0.4$ & $7.8 \pm 0.2$ & $1.5 \pm 0.0$ & $0.5 \pm 0.0$ \\
\hline & HEXAC & 30 & $17.7 \pm 0.3$ & $8.4 \pm 0.1$ & $1.8 \pm 0.0$ & $0.7 \pm 0.0$ \\
\hline & & 60 & $16.5 \pm 1.6$ & $8.2 \pm 0.1$ & $1.7 \pm 0.0$ & $0.7 \pm 0.0$ \\
\hline & SODSE & 5 & $20.3 \pm 0.1$ & $8.9 \pm 0.2$ & $2.0 \pm 0.0$ & $0.8 \pm 0.0$ \\
\hline & & 10 & $18.9 \pm 0.2$ & $8.6 \pm 0.1$ & $1.8 \pm 0.0$ & $0.7 \pm 0.0$ \\
\hline Overall VST & & & $17.7 \pm 1.9$ & $8.4 \pm 0.4$ & $1.8 \pm 0.1$ & $0.7 \pm 0.1$ \\
\hline \multirow[t]{5}{*}{ FST } & Control & 0 & $18.9 \pm 0.1$ & $9.4 \pm 0.2$ & $1.6 \pm 0.1$ & $0.6 \pm 0.0$ \\
\hline & HEXAC & 30 & $20.9 \pm 0.1$ & $10.0 \pm 0.1$ & $2.2 \pm 0.0$ & $0.9 \pm 0.0$ \\
\hline & & 60 & $19.6 \pm 0.1$ & $9.7 \pm 0.1$ & $2.0 \pm 0.0$ & $0.9 \pm 0.0$ \\
\hline & SODSE & 5 & $24.8 \pm 0.1$ & $10.7 \pm 0.4$ & $2.7 \pm 0.0$ & $1.7 \pm 0.0$ \\
\hline & & 10 & $21.8 \pm 0.0$ & $10.1 \pm 0.1$ & $2.0 \pm 0.1$ & $1.2 \pm 0.2$ \\
\hline Overall FST & & & $21.2 \pm 1.9$ & $10.0 \pm 0.5$ & $2.1 \pm 0.4$ & $1.1 \pm 0.4$ \\
\hline \multirow[t]{5}{*}{ Overall treatments } & Control & 0 & $17.0 \pm 2.1$ & $8.6 \pm 0.9$ & $1.6 \pm 0.0$ & $0.6 \pm 0.1$ \\
\hline & HEXAC & 30 & $19.3 \pm 1.7$ & $9.2 \pm 0.9$ & $2.0 \pm 0.2$ & $0.8 \pm 0.1$ \\
\hline & & 60 & $18.0 \pm 2.0$ & $9.0 \pm 0.8$ & $1.8 \pm 0.2$ & $0.8 \pm 0.1$ \\
\hline & SODSE & 5 & $22.5 \pm 2.4$ & $9.8 \pm 1.0$ & $2.3 \pm 0.4$ & $1.2 \pm 0.5$ \\
\hline & & 10 & $20.3 \pm 1.6$ & $9.4 \pm 0.8$ & $1.9 \pm 0.2$ & $1.0 \pm 0.3$ \\
\hline \multicolumn{7}{|l|}{ F ratio } \\
\hline Treatments & & & $91.8^{* * *}$ & $37.3^{* * *}$ & $390.1^{* * *}$ & $490.6^{* * *}$ \\
\hline GRS & & & $303.3^{* * *}$ & $562.0^{* * *}$ & $745.9 * * *$ & $1504.3^{* * *}$ \\
\hline Treatments $\times$ GRS & & & $2.0 \mathrm{~ns}$ & $0.9 \mathrm{~ns}$ & $95.0^{* * *}$ & $204.3^{* * *}$ \\
\hline
\end{tabular}

*** highly significant

Different variations were found in $\mathrm{MCH}$, yield, and PHOSP due to SODSE treatments that may be due to the increase in CHL, respiration rate, and activity of GSH-Px of mitochondria and dry material (Breznik et al. 2005; Germ and Osvald 2005; Smrkolj et al. 2006; Emam et al. 2014). The increases in PHOSP with SODSE treatments have been decided (Xue et al. 2001; Valkama et al. 2003; Lefsrud et al. 2006). The increasing CHL under SODSE levels may be occurred by increasing the uptake of magnesium $(\mathrm{Mg})$ in leaves (Haghighi et al. 2016). The changes in the protein and various amino acids contents (phenylalanine, aspartic acid, glutamic acid, threonine, tyrosine, isoleucine, leucine, lysine, methionine, valine, alanine, arginine, proline, cysteine, glycine, histidine, and serine) were confirmed by Jezek et al. (2011) in potato tubers (Solanum tuberosum L.). On the other hand, the effects of SODSE on enzymatic activities and productivity of dill under saline condition were investigated (Shekari et al. 2017); the results decided that SODSE caused various improvements in antioxidant enzymes activities and osmotic adjustment; therefore, adding SODSE under saline condition could be a better strategy for maintaining the dill productivity in arid regions. Application of SODSE with iodine resulted in an increase of carrot productivity (Smoleń et al. 2016).

\section{Conclusion}

In conclusion, the present investigation showed the impact of HEXAC or SODSE on growth, yield, and some chemical composition of $M$. oleifera. The best results were achieved at the doses of $5 \mathrm{mg} / \mathrm{L}$ (SODSE) and $30 \mathrm{mg} / \mathrm{L}$ (HEXAC). On the other hand, this study observed that the productivity of $M$. oleifera plants can be enhanced with SODSE and HEXAC applications. So this trial will help the farmers, the ministry of agriculture, and drug companies to improve the yield and active components $M$. oleifera as natural sources of drug industries.

\section{Abbreviations}

CAT: Catalase; CHL: Chlorophyll; DWR: Dry weight of root; DWSH: Dry weight of shoot; FST: Flowering stage; FWR: Fresh weight of root; FWSH: Fresh 
weight of shoot; GRS: Growth stages; HEXAC: Hexaconazole; LEN: Leaf number; MCH: Morphological characters; ns: Insignificant; PHOTSP: Photosynthetic pigments; POX: Peroxidase; PW: Pod weight; ROL: Root length; SD: Standard divination; SODSE: Sodium selenate; STL: Stem length; SW: Seed weight; VST: Vegetative stage

\section{Acknowledgements}

The authors would like to thank the National Research Centre (NRC) for its facilitates during this scientific work.

\section{Funding}

No specific fund was supplied for this work.

\section{Availability of data and materials}

The datasets supporting the results are included within the article.

\section{Authors' contributions}

All authors have contributed significantly to the conception and design of the study, the interpretation of data, and the drafting and revision of the manuscript. All authors read and approved the final manuscript.

\section{Ethics approval and consent to participate}

The manuscript does not contain studies involving human participants, human data, or human tissue.

\section{Consent for publication}

The authors declare that the work has consent for publication.

\section{Competing interests}

The authors declare that they have no competing interests.

\section{Publisher's Note}

Springer Nature remains neutral with regard to jurisdictional claims in published maps and institutional affiliations.

\section{Author details}

'Botany Department, National Research Centre, Dokki, Cairo, Egypt.

${ }^{2}$ Medicinal and Aromatic Plants Department, National Research Centre, Dokki, Cairo, Egypt

Received: 4 March 2019 Accepted: 5 April 2019

Published online: 02 May 2019

\section{References}

Ahmed AMA, El-Kady FA, Khalid AK (2018) Comparison between salicylic acid and selenium effect on growth and biochemical composition of celery. Asian J Plant Sci 17:150-159

Anonymous (2016) Official methods of analysis, 20th edn. Association of official analytical chemists, Washington

Breznik B, Germ M, Gaberik A, Kreft I (2005) Combined effects of elevated UV-B radiation and the addition of selenium on common and tartary buckwheat. Photosynthetic 43:583-589

Cartes P, Jara AA, Pinilla L, Rosas A, Mora ML (2010) Selenium improves the antioxidant ability against aluminum induced oxidative stress in ryegrass roots. Ann App Bio 156:297-307

Chamheidar H, Parvanak K (2014) Investigation of selenium fertilizer different rates on uptake of selenium in alfalfa plant. WALIA J 30:1-3

Chehelpar N, Tohidi-Moghadam HR, Ghoushchi F (2016) Hexaconazole foliar application alleviates water deficit effects in common bean. Pesq Agropec Trop Goinia 46:301-310

Chen TF, Zheng W, Wong YS, Yang F (2008) Selenium induced changes in activities of antioxidant enzymes and content of photosynthetic pigments in Spirulina platensis. J Int Plant Bio 50:40-48

Csiszr J, Szab M, Erdei L, Mrton L, Horvth F, Tari I (2004) Auxin autotrophic tobacco callus tissues resist oxidative stress the importance of glutathione $S$ transferase and glutathione peroxidase activities in auxin heterotrophic and autotrophic calli. J Plant Phys 161(6):691-699

Daughaday WH, Lowry OH, Rosebrough NJ, Fields WS (1952) Determination of cerebrospinal fluid protein with the folin phenol reagent. J Lab Clin Med 39:663

De-Smith MJ (2015) STATSREF statistical analysis handbook—a web-based statistics resource. The Winchelsea Press, Winchelsea, p 1
Dhanamanjuri W, Thoudam R, Dutta BK (2013) Effect of some pesticides (fungicides) on the germination and growth of seeds / seedlings of some crop plants, (Cicer arietinumand and Zea mays). Middle-East J Sci Res 17:627-632

Djanaguiraman M, Devi DD, Shanker AK, Sheeba A, Ban-garusamy U (2005) Selenium an antioxidative protectant in soybean during senescence. Plant Soil 272:77-86

Ebrahimi N, Hartikainenb H, Simojokib A, Hajibolandc R, Seppnen M (2014) Dynamics of dry matter and selenium accumulation in oilseed rape (Brassica napus $\mathrm{L}$.) in response to organic and inorganic selenium treatments. Agri Food Sci 24:104-117

Emam MM, Khattab HE, Helal NM, Deraz AE (2014) Effect of selenium and silicon on yield quality of rice plant grown under drought stress. Aus J Crop Sci 8(4): $596-605$

Farooq F, Rai M, Tiwari A, Khan AA, Farooq S (2012) Medicinal properties of Moringa oleifera an overview of promising healer (review). J Med Plant Res 6: 4368-4374

Feng Z, Guo A, Feng Z (2003) Amelioration of chilling stress by TDM in cucumber seedlings. Plant Growth Regu 39(3):277-283

Filek M, Keskinen R, Hartikainen H, Szarejko I, Janiak A, Miszalski Z, Golda A (2008) The protective role of selenium in rape seedlings subjected to cadmium stress. J Plant Phys 165:833-844

Fletcher RA, Gill A, Davis TD, Sankhla N (2000) Triazoles as plant growth regulators and stress protectants. Hort Rev 24:55-138

Germ M, Osvald J (2005) Selenium treatment affected respiratory potential in Eruca sativa. Acta Agric Slov 85(2):329-335

Germ M, Stibilj C (2007) Selenium and plants. Acta Agric Slov 89:65-71

Gomathinayagam CA, Jaleel M, Lakshmanan GM, Panneerselvam R (2007) Changes in carbohydrate metabolism by triazole growth regulators in cassava (Manihot esculenta Crantz); effects on tuber production and quality. C R Bio 330(9):644-655

Gopi R, Abdul-Jaleel C, Sairam R, Lakshmanan GMA, Gomathinayagam M, Panneerselvam R (2007) Differential effects of hexaconazole and paclobutrazol on biomass, electrolyte leakage, lipid peroxidation and antioxidant potential of Daucus carota L. Colloids Surfaces B Biointerfaces 60(2):180-186

Haghighi M, Sheibanirad A, Pessarakli M (2016) Effects of selenium as a beneficial element on growth and photosynthetic attributes of greenhouse cucumber. J Plant Nut 39(10):1493-1498

Hawrylak-Nowak B (2009) Beneficial effects of exogenous selenium in cucumber seedlings subjected to salt stress. Bio Trace Elem Res 132:259-269

Haya BA, Abdullah MY, Tajarudin NK (2017) The effects of oil palms empty fruit bunch compost with hexaconazole on biomass production and nutrient contents of sweet potato var. VitA to cultivated on sandy soil. Aust J Crop Sci 11:83-94

Hojati M, Modarres-Sanavy SAM, Ghanati F, Panahi M (2011) Hexaconazole induces antioxidantprotection and apigenin-7-glucoside accumulation in Matricaria chamomilla plants subjected to drought stress. J Plant Phys 168(8):782-791

Irmak S (2017) Effects of selenium application on plant growth and some quality parameters in peanut (Arachis hypogaea). Pak J Bio Sci 20:92-99

Jaleel CA, Gopi R, Manivannan P, Kishorekumar A, Sankar B (2016) Panneerselvam paclobutrazol influences on vegetative growth and floral characteristics of Catharanthus roseus (L.) G. Don. Indian J App Pure Biol 21:369-372

Jezek P, Hlusek J, Losak T, Juzl M, Elzner P, Kracmar S, Bunka F, Martensson A (2011) Effect of foliar application of selenium on the content of selected amino acids in potato tubers (Solanum tuberosum L.). Plant Soil Env 57(7):315-320

Jozwiak W, Mleczek M, Politycka B (2016) The effect of exogenous Se on the growth and photosynthetic pigments content of cucumber seedlings. Fre Envir Bull 25:142-152

Kar M, Mishra D (1976) Catalase, peroxidase and polyphenol oxidase activities during rice leaf senescence. Plant Phys 57:315-319

Kathleen MC, Allardo GT, Benson WRO, Martin A (2003) Effects of selenium supplementation on four agricultural crops. J Agric Food Chem 51:704-709

Khalid AK, Ahmed MA (2017) Growth and certain biochemical components of black cumin cultivated under salinity stress factor. J Mat Env Sci 8:7-13

Khalid AK, Amer HM, Wahba HE, Hendawy SF, Abd El-Razik TM (2017) Selenium to improve growth characters, photosynthetic pigments and essential oil composition of chives varieties. Asian J Crop Sci 9:92-99

Khalid AK, Shedeed MR (2014) Influence of kinetin on growth and biochemical accumulation in Nigella sativa plants grow under salinity stress conditions. Thai J Agric Sci 47:195-203

Kim TY, Hong JH (2012) Effects of hexaconazole on growth and antioxidant otential of cucumber seedlings under UV-B radiation. J Env Sci 21:1435-1447 
Lefsrud MG, Kopsella DA, Kopsella DE, Randle WM (2006) Kale carotenoids are unaffected, whereas biomass production, element concentrations, and selenium accumulation respond to changes in selenium fertility. J Agric Food Chem 54(5):1764-1771

Lyons GH, Genc Y, Soole K, Stangoulis JCR, Liu F, Graham RD (2009) Selenium increases seed production in Brassica. Plant Soil 318:73-80

Mareeswari P (2002) Bio-efficacy and persistence of hexaconazol against okra powdery mildew (Ensiphe cichoracearum DC) and chilli powdery mildew (Leveillula taurica (Lev.) Arn.). Ph. D thesis. Tamil Nadu Agricultural University, Coimbatore

Mozafariyan M, Pessarakli M, Saghafi K (2017) Effects of selenium on some morphological and physiological traits of tomato plants grown under hydroponic condition. J Plant Nut 40:139-144

Mukherjee SP, Choudhuri MA (1983) Implications of water stress-induced changes in the levels of endogenous ascorbic acid and hydrogen peroxide in vigna seedlings. Plant Phys 58:166-170

Nancy D, Arulselvi PI (2014) Effect of selenium fortification on biochemical activities of tomato (Solanum lycopersicum) plants. Indo Amer J Pharm Res 4(10):3997-4005

Shekari F, Abbasi A, Mustafavi SH (2017) Effect of silicon and selenium on enzymatic changes and productivity of dill in saline condition. J Saudi Soc Agric Sci 16(4):367-374

Sivakumar T, Sundaramanickam A, Panneerselvam R (2009) Changes in growth and pigment content in sweet potato by triadimefon and hexaconazole. J Phytol 1:333-341

Smoleń S, Skoczylas Ł, Ledwożyw-Smoleń I, Rakoczy R, Kopeć A, Piątkowska E, Bieżanowska-Kopeć R, Koronowicz A, Kapusta-Duch J (2016) Biofortification of carrot (Daucus Carota L.) with iodine and selenium in a field experiment. For Plant Sci 7:1-17

Smrkolj P, Germ M, Kreft I, Stibilj V (2006) Respiratory potential and Se compounds in pea (Pisum sativum L.) plants grown from Se enriched seeds. J Exp Bot 57(14):3595-3600

Statsoft (2007) Statistica version 7.1. Statsoft Inc, Tulsa

Valkama E, Kivimaenpaa M, Hartikainen H, Wulff A (2003) The combined effects of enhanced UV-B radiation and selenium on growth, chlorophyll fluorescence ultrastructure in strawberry (Fragaria ananassa) and barley (Hordeum vulgare) treated in the field. Agric For Met 120(1-4):267-278

Xue T, Hartikianen H, Piironen V (2001) Antioxidative and growth promoting effect of selenium on senescing lettuce. Plant Soil 237(1):55-61

Yassen AA, Khalid KA (2009) Influence of organic fertilizers on the yield, essential oil and mineral content of onion. Int Agrophys 23:183-188

Zhang L, Duan X, Tian Z, He J, Li B, Wang Z (2007) Uniconazole induced tolerance of soybean to water deficit stress in relation to changes in photosynthesis, hormones and antioxidant system. J Plant Phys 164:709-717

\section{Submit your manuscript to a SpringerOpen ${ }^{\circ}$ journal and benefit from:}

- Convenient online submission

- Rigorous peer review

- Open access: articles freely available online

- High visibility within the field

- Retaining the copyright to your article

Submit your next manuscript at $\boldsymbol{\nabla}$ springeropen.com 